\title{
Inequality in Professional Service Encounters: Verbal Strategies of Control versus Task Performance in Calls to the Police
}

\author{
Peter Eglin/Doug Wideman 1,2 \\ Department of Sociology and Anthropology, Wilfrid Laurier University, Waterloo, Canada N2L 3C5 \\ Faculty of Community and Social Studies, Newcastle upon Tyne Polytechnic, Newcastle upon Tyne, NE1 8ST, \\ Großbritannien
}

\begin{abstract}
According to the interactional form of the professional dominance (PD) thesis professional service encounters, especially of the medical sort, are arenas of negotiation, conflict or struggle in which professional service providers attempt to dominate lay service seekers through various verbal strategies for controlling the definition of the situation, the interactional agenda and the time and resources expended in the encounter. Prominent among these purported linguistic strategies are the use of interruptions, questions (and particular types of questions) and silences. Service seekers are correspondingly said to resist such attempts at control. In this paper we criticize the PD thesis as it applies to interruptions and questions through a brief re-examination of some of the analyses by $\mathrm{C}$. West and by Scheff of medical and psychiatric encounters, and through a longer scrutiny of a corpus of calls to the police. Not finding any evidence of these verbal control strategies we propose an alternative ethnomethodological (conversation-analytic) account of the occurrence of overlaps (in West's data) and of the so-called 'abruptness', 'constraining influence' and 'asymmetry' of questions in calls to the police. We locate these apparent features in a general account of the interactional shape of the calls, an account which sees that shape as a concerted accomplishment of the parties to them. That accomplishment, we claim, derives from the parties' mutual orientation to (a) the occasion of the call as one directed to the performance of a set of tasks, which establish (b) the relevance of co-identification in terms of a particular set of identities and (c) a characteristic distribution of speakers' rights to turns at talk. While not disputing (here) the structural version of the PD thesis we wish to replace the interactional version of it by an approach which begins to address how the institutional interaction reproducing that structure is produced as such in the first place.
\end{abstract}

\section{Professional Dominance}

The 'professional dominance' thesis (Freidson, 1970; Johnson, 1972) was originally developed to explain the social organization of medical care. It was a 'structural' thesis. Gross features of the phenomenon in question, namely the provision of medical care, were seen to be consequences of a certain arrangement of the social structure, namely that medicine is organized in the form of a profession and that that profession has come to dominate the provision of that care. But from the beginning the thesis received an interactional interpretation. Not only is professional power institutionalized in that the relationship between service provider and service seeker is carried on as one between a 'professional' and a 'client', but, it was argued, that power is exerted and expressed in the forms of 'control' by which the doctor dominates the patient in the consultation itself (Scheff, 1968; Strong, 1979a: 128ff.; Fisher, 1982: 58).

So interpreted the thesis was attractive to those looking for the sociological missing link - the bridge between micro and macro levels of analysis. Something of a convergence occurred between Marxists looking down in search of an analysis of the professions in terms of the hegemony of the ruling class (Waitzkin, 1979; cf. Strong, 1979c) and interactionists looking up in search of the institu- tional distillations of micropolitical processes (Atkinson, 1981). A further element has been added by the emergence of feminist-inspired analyses of gender control in professional/client encounters (West, 1984a; Thorne, Kramarae and Henley,

${ }^{1}$ Doug died of cancer between first and last revisions of this paper. Not being able to revise his death, I dedicate these last revisions to his cherished memory. I miss him a lot.

${ }^{2}$ For their support of this research we would like to thank the Nelsonville Regional Police. Wilfrid Laurier University, the Alexander von Humboldt Foundation, the Social Sciences and Humanities Research Council of Canada, die Universität Konstanz, the Centre for Socio-Legal Studies at Wolfson College Oxford, Thomas Luckmann, Jörg Bergmann, Sigrid Ziffus, Jörg Fuhrmann, Susanne Uhmann, Jürgen Schmuker, Max Atkinson and Don Harris. For their helpful comments on previous drafts we thank Bob Anderson, Peter Auer (particularly for collaboration on the analysis of extract (2)), Laird Christie, John Heritage, Jim Schenkein, Wes Sharrock and the excellent anonymous reviewer. Earlier versions were presented at the Annual Conference of the British Sociological Association at Aberystwyth in April 1981 and in a workshop session of the International and Multidisciplinary Conference on Interaction and Language Use at Plymouth in July 1984 at which Paul Drew and Peter Manning made helpful comments. 
1983: section VF7 'Worksettings'). Outside of professional sociology the growth of discourse analysis in linguistics has focussed attention on the interactional or pragmatic context of individual utterances such as those in professional service encounters (Di Pietro, 1982), and here too the professional dominance thesis enjoys considerable currency (for example, Haberland and Mey, 1981: 105-106; Bogoch and Danet, 1984).

An interest in the relatively close analysis of naturally occurring, spoken interaction has brought 'professional dominance' (PD) studies - whether of Marxist, symbolic interactionist, pragmatic-linguistic or mixed provenance, with or without feminist concern (Strong, 1979b: 213, fn. 13) - into contact with 'conversation analysis' (CA).

"Conversation analysis has developed over the past [twenty] years as a distinctive research stream of the wider intellectual program of ethnomethodology - the study of the commonsense reasoning skills and abilities through which the ordinary members of a culture produce and recognise intelligible courses of action. Throughout the period of its public existence, the perspective has been distinctive both in its commitment to the study of naturally occurring interaction and in its avoidance of idealized theoretical and empirical treatments of its chosen research materials"

(Heritage, 1985a: 1).

\section{Moreover, for CA}

"the past five years or so have witnessed a steady development of interest in the study of various forms of 'institutional' interaction involving strongly defined social roles - in particular, classroom, courtroom, news interview, doctor-patient, social worker-client and other institutional forms of interaction"

(Heritage, 1985a: 7).

While PD studies have increasingly borrowed concepts from CA, the latter has tended to develop its

${ }^{3}$ On doctor/patient interaction compare, for example, the studies by Patrick West, Bloor and Coulthard and Ashby in Wadsworth and Robinson (1976) and those by Candace West and Lacoste discussed below in the text with Sharrock (1979) and Anderson and Sharrock (forthcoming). On teacher/student interaction compare, for example, Edwards and Furlong (1978; also Walker 1980) and Cazden (1979) with McHoul (1978, 1979), Heap (1979), Mehan (1979), the studies in Payne and Cuff (1982) and that by McHoul and Watson (1984). On courtroom and lawyer/client interaction compare, for example, Carlen (1976), Danet and Bogoch (1980), O'Barr (1982) and Bogoch and Danet (1984) with Atkinson and Drew (1979), Dunstan (1980), Drew (1985) and Groves (1973). On the psy- institutional analyses via criticism of the former approach. The studies of West (and of Zimmerman and West) occupy perhaps a special place in that they exhibit considerable 'overlap' of CA methodology and subscription to the PD thesis (and gender dominance thesis); we pay them particular attention. It is not our purpose to review formally the whole array of work nor to describe fully the debate in any one institutional area, ${ }^{3}$ but

(a) to contribute some observations from one area not previously explicitly considered in these terms, namely calls to the police,

(b) to suggest their critical relevance for the PD thesis, and

(c) to propose an alternative account based on an appreciation of the parties' primary orientation to the 'technical' task of getting through the business at hand in the encounter, an appreciation made possible by CA.

It is important to note for (b) that we are not criticizing the structural version of the dominance thesis as originally formulated by Freidson, but the interactional version. It is to the latter alone that 'professional dominance thesis' refers in what follows.

This interactional form of the dominance thesis has it, then, that professional/client service encounters are

- arenas of conflict, struggle or, at least, negotiation,

- over the definition of the situation, the interactional agenda, and the time and resources available,

- between contending parties with competing interests in the matter at hand.

The professional service provider is portrayed as one concerned to define the presenting 'complaint'

chiatric interview compare, for example, Scheff (1968), or even the formidable Labov and Fanshel (1977) with Turner $(1972,1976)$ and Bergmann (1982). On counsellor/client interaction compare, from different settings, Erickson and Shultz (1982) with Watson (1981, forthcoming b). On social worker/client interviews see Wilkinson and Grace (1975: 411-412), on news interviews Heritage (1985b), and on police interrogations Watson (fortcoming a).

In general compare Fowler et al (1979) with Sharrock and Anderson (1981), and Murdock (1976, 1980) with Anderson and Sharrock (1979; Sharrock and Anderson, 1982). For further references see Heritage (1985a) and Heritage and Atkinson (1984: 15, fn. 9). On customer service encounters see Merritt (1976). 
in terms that suit his (her?) professional, organisational, bureaucratic or, indeed, ruling class interests: he is interested in the disease rather than the patient's health, a manageable classroom rather than the student's education, a smoothly operating courtroom rather than justice for the defendant, a workable caseload rather than the welfare of his client. To enforce those interests, and this is where the specifically interactional claims arise, he is said to employ various strategies for controlling the service encounter. Among these are specifically (socio-)linguistic ones. Particular significance has been accorded to interruptions, questions and silences. In response to all this the service seeker is cast as one engaged in a verbal struggle to secure his/ her rights to have his/her needs serviced as he/she defines them.

Police/citizen interaction would seem to be a prime candidate for the operation of the dominance thesis. It is a sociological commonplace that social control is the function of the police. In terms of the dominance thesis, that function becomes the 'reproduction of order' in the interests of, at worst, the ruling class (Ericson, 1982). While the status 'professional' is one the police have struggled to acquire, 'to serve and to protect', is the intention announced by many a police cruiser's door. 'Professional service encounter' would seem then a not unapt description of the interaction that ensues when a citizen calls the police to report a trouble and request assistance. It may, however, seem strange even to consider that so apparently nonadversarial a form of interaction as calling the police should be examined for the presence of professional dominance. This, however, has not stopped analysts seeking, and apparently finding, its exercise in the apparently equally non-adversarial settings of the offices of doctors, lawyers and social workers. In so doing, we would claim, they have not only misrepresented the character of interaction in the settings in question, but overlooked important 'technical' differences among them (Anderson, 1981: 5-6; Freidson, 1970: 15).

Finally, the critical import of what follows for the relevance of the $\mathrm{PD}$ thesis to police/citizen interaction is restricted to the call to the police. Nothing said here rules out the possibility of the successful application of the thesis to subsequent stages of the criminal justice process. It should be noted, however, that the position argued here is consistent with the results of studies of police/citizen encounters and arrest (Black, 1976; see also Daudistel et al, 1979: chp. 3), of interrogation (Watson, forth- coming a), of plea-bargaining (Maynard, 1984), and of both plea-bargaining and calls to the police (Wilson, 1985). (I have become aware of this most relevant paper by Wilson only in putting the final editorial touches to this article).

Two important and difficult methodological tasks face the seeker of professional dominance:

(a) specifying what actions will count as the vehicles of PD in the encounter;

(b) specifying what linguistic forms (as available on the tape or in the transcript of the talk) will count as instances of those actions.

Since we regard both as fundamentally misguided, others' attempts to comply with them will provide us with opportunities for criticism in what follows. In the interest of clarity, comparability and critique we will comply with (a) by setting out for the police/citizen case what we take be the standard components of the PD thesis. If that thesis is true for calls to the police we would expect

(A) that police would seek to control the interaction

(AI) by interrupting caller to cut off his/her attempts to give a full and complete story which tells it from caller's point of view,

(AII) by asking questions which restrict the options open to caller to those serving police interests of control,

(AIII) by using silences (and related persuasive strategies) to put off or screen out callers' complaints that do not fit police conceptions of what is actionable, and that citizens would resist such control.

This scheme is partly derived from Scheff's pioneering (1968) symbolic interactionist study of the 'negotiation of reality', in the psychiatrist/patient interview. That we use it, along with West's work, as something of a stalking horse in what follows reflects only the admirable explicitness of its claims, something that permits easier criticism and thereby, hopefully, progress. Also we intend no blanket critique of any sociological perspective here, least of all symbolic interactionism which has given us Rubinstein's excellent ethnography of the 'phone man's' task (1973: 75).

The remainder of the paper is organised as follows. After a note on the data we treat the first two parts of proposition A in turn, saving (AIII) and (B) for a subsequent paper. In each section we both display data that do not support that part of the dominance thesis in question, and develop gross 
conversation-analytic and related observations that suggest a different account of the nature of the interaction. In a final section we attempt a somewhat more systematic summary of the thrust of these observations for the understanding of the typical course of police/citizen interaction on the telephone.

\section{A note on the Data}

Our corpus of data comprises 87 telephone calls made by citizens to the police on the emergency number in a Canadian city in the summer of 1978. The basis of the calls' selection was practical. Wideman had official access to the police communications room, took the first available tape and after listening for a while transcribed a sequence of calls until the (small) research grant was used up. We have no reason to believe that these are anything but run-of-the-mill calls. Some twenty-odd calls have been drawn on for this paper, limitations of space permitting only the shortest extracts. This is scientifically regrettable in that the validity and objectivity of CA depends strongly on the public availability of data for scrutiny by other investigators and critics. The long data excerpts Scheff provides are a further virtue of his article.

By Jefferson's standards our data are fairly grossly transcribed. (The transcribing conventions are listed in an appendix). Our 'conversation-analytic' observations are correspondingly gross in character, but we hope that both data and observations are adequate for the level of analysis we attempt.

Except where otherwise noted all the calls used here end up with some variant of 'Okay, we'll send someone over' said by the police. Each call is identified by the pseudonym of the place, its number in our corpus, the year and the time on the twenty-four-hour clock in hours, minutes and seconds. All personal and place names, telephone numbers and other possibly identifying references have been changed.

\section{Verbal Strategies of Control}

\section{(AI) Controlling Topic Development Through Interruptions}

Proponents of the dominance thesis frequently assert the ubiquity of interruption by the professional, but one is hard put to find cases in their data. For example, Coulthard and Ashby (1976) claim that the doctor "has his own ideas of what is relevant and irrelevant and will interrupt a patient who is wandering" (78), but no interruptions are indicated in the data they present; there is no overlap in the example they give of a 'fight' between doctor and patient (78). In Scheff's (1968: 8) psychiatric interview it is the patient who does the interrupting (at P95 and P96). In her study of hospital consultations Lacoste (1981) asserts that "control is entirely on the part of the doctor who may interrupt the patient almost at his or her liking" (170). But in the small number of data she presents, only one overlap (//) occurs, one that is readily analysable as a joint production of the parties speaking. We cite the English translation of the original French data.

(1) (Lacoste, 1981:173)
“(1) D: How are you doing?
(2) P: Fine// (3) Except that I caught a cold.
(4) D: A ... you know that ... you shouldn't fool around with things like that, you shouldn't.

(5) P: It's not dangerous."

\section{Notice}

(I) that P's 'Fine' answers D's 'How are you doing?', so permitting D to speak again,

(II) that "a pause separates (2) and (3)" (173, fn. 5), from which each speaker may infer that the other expects him or her to speak,

(III) that $\mathrm{P}$ and $\mathrm{D}$, not surprisingly, then produce simultaneous starts in (3) and (4) (assuming this is how we are to read Lacoste's transcript),

(IV) that despite the overlap $P$ produces a recognisable sentence in (3), and

(V) D, moreover, responds to it in (4). It is quite unclear why (a) the overlap should be regarded as an interruption, and why (b) this so-called interruption' should be regarded as an instance of the exercise of professional power.

Rather, the pause and simultaneous starts are the product of the parties' orientation to at least the turn-allocational rules for conversation - "if a current speaker has not selected a next speaker, and if no one else self-selects at an initial transitionrelevance point, then the third rule applies, which is that the current speaker may (but does not have to) continue. ." (Atkinson and Drew, 1979: 38; also 46 and 238 , fn. 9 for a comparable case) - and perhaps also to the diagnostic relevance in this setting of what is otherwise a (non-diagnostic) greeting substitute, 'How are you doing?' (Sacks, 1975). 
Over the last ten or so years West's work, in part with Zimmerman, first on cross-sex conversation (Zimmerman and West, 1975; West, 1979; West and Zimmerman, 1983: 113-114) and subsequently on physician/patient talk (West, 1983, 1984a, 1984b), shows a progressive sophistication in (a) distinguishing 'overlap' and 'interruption' and (b) the interpretation of interruption as the exercise of professional power. Nevertheless, her analyses are not unproblematic, as in the following case.

(2) (West, 1984a:96-97; also 1983:90-91)

" $($ Here, the doctor is inquiring about a recent injury to the patient's back caused by an auto accident.))

Patient: When I'm sitting upright. Y'know=

Physician: $=$ More so than it was even before?

Patient: Yay::es=

Physician: $\quad=$ Swelling 'r anything like that thet chew've

no:ticed?

Patient: Nuh:o,
Physician: not the $\left[\begin{array}{l}\mathrm{t} \text { I've nodi- } \\ \text { TEN::DER duh the tou }\end{array}\right] \mathrm{ch}$ ? Press:ing any?

Patient: No:, jus' when it's-si::tting.

Physician: Okay:=

Patient: = Er lying on it.

Physician: Even ly:ing. Stan:ding up? Walking aroun:d? ((sing-song))

$\left.\begin{array}{l}\begin{array}{l}\text { Patient: No: } \\ \text { Physician: }\end{array} \\ \text { Jis' then". } \\ \text { Not so mu:ch. }\end{array}\right] \begin{aligned} & \text { Jis'-ly:ing on it. } \\ & \text { Si:tting on it. }\end{aligned}$

The extract purportedly supports the general contention that "interruptions function as topic control mechanisms" (Zimmerman and West, 1975: 124) and the more specific claim that (male) doctors appear "to use interruptions as devices for exercising control over interaction" (West, 1984a: 101), thereby preventing patients contributing important information relevant to the care of their health, indeed to the diagnosis of their condition.

But notice in (2) that

(I) the first overlap occurs, as in (1), when the patient continues talking after having answered the doctor's question;

(II) the 'not th' projects a readily analysable (by the hearer) completion, namely 'not that I've noticed', which recipient need not wait to hear before proceeding - the appended item itself foreseeably adding little;
(III) patient's fourth utterance is not overlapped after its minimally sufficient answer of 'No::' but left to apparent completion;

(IV) patient's fifth utterance is an unsolicited item (a self-repair?) that is nevertheless taken account of in the doctor's 'Even ly: ing';

(V) the second overlap occurs again as in (I), but with the doctor nevertheless retrieving what, in overlap, he may well suppose the patient would have said, 'Jis'-ly:ing on it'.

If these overlaps are interruptions they occur at projectively and interactionally relevant places, they are joint productions, they are general to conversation, the doctor does listen to more than 'yeses' and 'no's', and the patient complies.

Here (West, 1984a: 91) and elsewhere (West, 1979: 82; Zimmerman and West, 1975: 114; West and Zimmerman, 1983: 104) West seeks to establish a (socio-)linguistically formal criterion (though it gets broader and weaker in the footnotes of one article to the next) for what appears to be conceptualized as a type of speech act: the speech act of interruption is to be identified by the point at which overlap commences relative to the possible completion points of what Sacks et al (1974) call 'unit-types'. Interruptions may be 'shallow' or 'deep' according to the distance in syllables from those points. Unit-types are words, phrases, clauses and sentences, that is, grammatical units. The problem is that interruptions are not done on grammatical units per se (or even perhaps on turns?) but on actions (answers, jokes, explanations): in Austin's (1962) terms, they happen to illocutionary, not locutionary, acts. Thus, they may occur in the midst of a given grammatical unit, or at a turn-transition-relevant place if the current speaker should continue talking. (Not all stories are prefaced so as to suspend turn-transition relevance). But whether overlaps such as those in (1) and (2) are to be regarded as interruptions depends not on the observer's application of a linguistic criterion but on the speakers' assessment of the completion of some relevant action. From the perspective of conversationalists in medias res, completion may take some indefinite number of unittypes to accomplish. While the overt topicalizing of interruptions by speakers is not necessarily a guide to their having occurred, the former arguably being rare in comparison to the latter (Zimmerman and West, 1975: 123-24; West, 1979: 93-94; West and Zimmerman, 1983: 104, 111; see Heritage and Atkinson, 1984: 11), it is likely some guide to their interactional significance for the speakers at the 
time. Whether either case pertains to the exercise of power and control in the talk is a further issue (West and Zimmerman, 1983: 111), one better discussed in a subsequent section. These remarks also apply to the analysis of the distribution of 'interruptions' in Bogoch and Danet (1984: 254-255). The reader may wish to consult Schegloff's (forthcoming) argument that there are more criteria of 'success' in competitive talk than 'survival' in overlap.

In the calls-to-the-police data interruptions virtually never take place. Indeed, callers are frequently simply let to run on until they 'trail off' (see point ii) in the summary of the paper). More commonly, however, the police could be said, naively, to be too easily satisfied since they appear willing to take minimal descriptions as the basis on which to act, not needing to elicit lengthy details about the particular events and persons involved, but proceeding upon the basis of conventional activity descriptors and social identity categories (Sacks 1972a). Note in (3) below 'a bunch of boys' and 'upsetting the lumber piles one thing and another' in $\mathrm{Cl}$, and in (4) 'Marital' in $\mathrm{C} 2$.

(3) (Nelsonville/*27/1978/03-43-29)

P1 Police, fire ambulance (3.5) Hello?

C1 Hello, listen I think uh there's a bunch of boys in the Panel Veneer in the lumb I'm not quite sure, I think there is, they're upsetting the lumber piles one thing and another.

P2 Okay, whereabouts is this located on uh:

$\mathrm{C} 2$ On, on uh Joanne.

P3 On Joanne, Panel Veneer

C3 Yes.

P4 Okay, we'll check it sir.

C4 Okay.

P5 Thank you.

(4) (Nelsonville/*33/1978/00-32-47)

P1 Emergency Centre.

C1 Yes right, ten thirty-five uh Schwartz street please(h).

P2 What's your problem there?

C2 Marital.

P3 And what's your name?

C3 Smith(h).

P4 What's your first initial Mr. Smith

C4 L(h).

P5 Okay, is that an apartment or a house?

C5 Uh.

P6 At ten thirty-five Schwartz?

C6 Right(h).

P7 Is that an apartment or a house?

C7 It's a, it's a house(h), semi-detached(h).

P8 Okay, and what's the telephone number there?
C8 One three two eight two three six (h).

P9 Okay, we'll send somebody over right away.

C9 Right(h).

P10 Thank you.

(Note: A woman's voice could be heard in the background.)

In (5) notice 'large party .. of young people', 'all over our golf course' and 'some vandalism' in C2. In (6) notice 'two boys', 'beating up on' and 'little kids' in $\mathrm{C} 3$.

(5) (Nelsonville/*13/1978/22-28-24)

P1 Emergency Centre.

C1 Yes, I'm calling from the Affluent Golf and Country Club//I'm =

P2 Yes.

$\mathrm{C} 2=$ the assistant manager here and in a home adjacent to our property there's an extremely large party in progress of young people and they're all over our golf course and I'm a little bit worried about some vandalism.

P3 Allright.

C3 Thank you.

P4 And what is your? name

(6) (Nelsonville/*66/1978/14-41-43)

P1 Emergency Centre.

C1 Uh, I would like the police please.

P2 This is the police mam. What's the problem

C2 I'm from Jackson Hill pool in Oldtown.

P3 Uh-hu.

C3 And we've had two boys beating up on the little kids out here and now I have their names and it's not really a total emergency sort of thing but I would like someone to come up and ah talk to these fellows.

P4 Okay. So that was Jackson Hill pool?

Though, as we shall see in (AII), the police do ask questions seeking a clarification, selection or reformulation of some of the particulars, for the most part they are satisfied with the sort of minimal or generalized descriptions of persons and events illustrated here.

The calls differ in this way from both police interrogations (Watson, 1983; forthcoming a) and courtroom examination (Atkinson and Drew 1979; Dunstan 1980). Not that the difference is one of the exercise of greater or lesser power, but of the different 'technical' requirements of the activities involved. Most often it is plain enough:

(I) from the relationship between the time of the call and the time of the complainable, from the fact, that is, displayed by the caller that he/she has called at the first opportunity (Sharrock and Turner 1978; Eglin and Wideman 1979), 
(II) from the day and time of the call itself - for example, 'late Friday night' (Sacks 1972c: 286-87),

(III) from the whereabouts of the complainable 'A park', 'B hotel', 'C tavern', 'D street', 'E rooming houses', ' $F$ bank' (Bittner 1967: 707; Sudnow 1965: 261; Eglin 1980b),

(IV) from the 'category-bound' nature of the activities - 'boys' 'beating up on' 'kids' (Sacks 1972b),

(V) from the fact that the call has been made at all (Bittner, 1974: 32), and

(VI) from the fact that for many cases the police can withdraw from acting if the complainant withdraws the complaint (Black, 1976 (1971): 60-61; Reiss, 1971: 83; Shearing, 1974: 83, 84; Errington, 1973: 41),

what sort of call this organizationally is and how adequate the offered description is for purposes of taking action. Looking for interruptions just does not begin to handle these matters.

\section{(AII) Restricting Options Through Questions}

The professional dominance thesis asserts that professionals exert power in service encounters and control service seekers, both by being the ones who ask the questions, and by the sort of questions they ask. Borrowing the concept of pre-allocation of turn type and turn size from CA, analysts such as West (1983) have used it in a way quite unwarranted by CA to justify enumerating the distribution of questions between the interactants. A marked asymmetry in the distribution is then used as an indicator of 'power to the questioner'. As with the case of interruptions both steps require considerable methodological work to accomplish. Just as interruptions have to be separated from other forms of overlap, such as third-turn overlapping repair (Heritage and Atkinson, 1984: 9-10), so information-seeking questions have to be separated from repair objects bearing interrogative intonation. Though West displays considerable skill in the matter (cf. Danet and Bogoch, 1980) it nevertheless remains that she is engaged in a constructive enterprise, one in which coding decisions ultimately rest on her shoulders no matter how much she acknowledges that the asymmetry in question distribution is a co-production of the parties. The difficulty is illustrated in (7) where she conjures constraint of the patient by the doctor out of a problem of her own devising, namely whether there are three 'queries' here or one.
"When patients failed to answer their physician's questions, it was often under constraining structural circumstances. For example, when physicians chained questions together with no intervening slots for answers, the individual queries that comprised the chains frequently failed to elicit patient's responses: [see (7)]. Thus, in this fragment, if 'chi::lls?', 'shakin' chi::lls?' and 'high fever?' constitute three separate queries, it is not clear to which, if any, of them the patient ventures a reply" (West, 1983: 89).

(7) (West, 1983: 89)

"Doctor: NO:chi::lls? shakin' chi::lls? $=$
Patient: $\quad=\left[\begin{array}{l}\text { Don'- } \\ \text { high }\end{array}\right]$ fever? $=$
Doctor:
Patient: $=$ No:, jis- (.) slee:ping (.) alo:t (.) too:
Doctor: $\left[\begin{array}{l}\text { That- } \\ 0\end{array}\right]$ kay".

What is surely clear is that West's problem does not arise for the parties. The doctor's 'Okay' apparently signals satisfaction with the patient's previous answer which itself seems to deny that any of the one, two or three conditions obtains, rather she/he just sleeps a lot, a condition not contained in the doctor's list of options. How the parties are analysing the talk such that they make these understandings available to each other, and thereby to the overhearing observer, is not described by West. That the doctor's accomplishing of a string of three 'queries' is dependent on the patient's not speaking after the first (may not 'shakin' chi::lls?' be a selfcorrection of 'chi::lls?'? (Bergman: 1981)), and dropping out of overlap after the second, is not noted by West (see Schegloff, 1981: 89). Most telling, she does not say, in the end, how she coded this extract for 'questions'.

The point bears repeating. The fundamental problem with this analytic strategy is that, as with interruptions, there is no mapping of actions (question/answer) onto grammatical (interrogative/declarative), or indeed sequential, forms independently of speakers' own analyses/hearings of the talk (Austin, 1962; Schegloff and Sacks, 1974: 241-242; Wootton, 1975; Turner, 1976: 249; Harris, 1981; Schegloff, 1984: 29-36; Sharrock and Watson, 1984: 438).

If this argument applies to 'questions' in general, then it applies also to the different types of question observers distinguish. Here we will re-introduce the second methodological step, that of making out particular action-types (here questions and their types) to be indicators of the exercise of 
professional control. If, according to the PD thesis, questioning itself affords the questioner a degree of control, then 'direct' questions (Scheff, 1968: 16) are said to increase it. Of this type, at least four sub-types are usually distinguished, namely 'facesheet' questions, what are variously called 'closed', 'yes/no' or 'polar' questions, 'either/or' questions and 'open' or 'wh' questions (Danet and Bogoch, 1980: 43). In contrast to the last sub-type, the other three are said to constrain the answerer, restricting his/her options to tell his/her story from his/her point of view. Observers often find these questions to be asked in a bureaucratic, impersonal way with frequent or sudden or random changes of topic (for example, Bogoch and Danet, 1984: 256). But such observations seem to take no account of the business of the talk, and rarely survive even cursory examination of its interactional organization.

For example, in his analysis of a section of a now classic psychiatric interview - first gathered by Gill, Newman and Redlich (1954), and subjected to 'microscopic analysis' by Pittenger, Hockett and Danehy (1960) - Scheff (1968) interprets the therapist's (T) 'facesheet' question "How old are you?" in response to the patient's (P) "I'm a nurse, but my husband won't let me work" as "changing the subject" and not "responding to the last part of her answer, which would be expected in conversation between equals" (15). See (8), where we use Turner's transcription.

(8) (Turner, 1976: 234)

T6 Sure. What do you do?

P6 I'm a nurse, but my husband won't let me work.

T7 How old are you?

P7 Thirty-one, this December.

T8 What do you mean, he won't let you work? (Clears throat)"

In contrast, Turner (1976) provides a conversationanalytic account of how it is

(I) that we may hear T7 as indeed on-topic, as addressed to the hinted complaint in the second part of P6, "as saying, in effect, 'Are you a child, that you pass on that responsibility to others?', or 'Surely you're old enough to be responsible for your own decisions?"” (253);

(II) that we may consequently find P's 'facesheet' answer in P7 to be the product of a mis-hearing; and

(III) that therefore T8 "figures not as a 'delayed' response to P6 (as Pittenger et al would have it), but as a reformulation of 'How old are you?'” (253, fn. 16; see also Wootton, 1975: 64-75; Eglin, 1980b; Schegloff, 1984: 40-41; see P4 in (12) below).

We would add to this only that "How old are you?" may well be doing both the organizational work of gathering facesheet information and the therapeutic work of addressing the patient's trouble (as well as the conversational work of staying on topic). We hasten to add further that this is not said with the pusillanimous intent of occupying the middle ground on this question. Rather it is to apply the argument of Sacks (1971 [April 30]), formulated by Anderson and Sharrock (forthcoming [ms.]: 14) as a "principle of opportunism", to the effect that service-providers make use of whatever materials come to hand in the course of consultations, to gather the information that has to be gathered, while simultaneously making their inquiries ones that fit the troubles of this patient, this client, this seeker of service.

When we address the calls to the police it is not necessary to speculate about what the connection may be between imputed class, power and control interests of the police and what they say. For it is clear enough that the questions they do ask are for the most part bent towards interactional-organizational matters of managing the call as a sequence of work tasks. As Anderson and Sharrock (forthcoming [ms.]: 12) argue for the medical encounter, through the use, for example, of 'correction solicitors' such as 'Right-now-um-you he he's supposed to be having a six month check today is he', "The doctor is not, as might appear at first sight, closing down options and operating professional power. Rather he chooses to make such options available should the patient want them, while at the same time he is moving from one phase to the next phase in the activities"

(Anderson and Sharrock, forthcoming (ms.): 12).

A gross characterization of the work tasks of the police phone man/woman would include establishing police identity, receiving and accepting/declining the complaint, gathering information to determine the organizational seriousness of the complainable, deciding on and communicating the disposition and closing the call (Zimmerman, n. d.: 2-3). Here we illustrate three such tasks as they are accomplished through questions.

(a) Accepting the complaint and moving to information gathering.

Consider the fact that for these calls a standard way to accept a complaint is to launch into the question-answer sequence by way of a question 
that does not tie closely to the previous utterance, but thereby is hearable as addressing the complaint-delivery as a whole (Sharrock and Turner 1978: 175). Look back to P2 in extract (3), P3 in (4), P4 in (5), P4 in (6) and note the indicated turns in the following extracts.

(9) (Nelsonville/*1/1978/01-49-30)

P1 Emergency Centre.

$\mathrm{C} 1$ Could you give me the police please.

P2 You have the police sir. What is your problem.

C2 Yea officer, could you come to two (0.5) twenty Tree Place or two thirty one $C$ Upland Place.

P3 Two thirty one? Upland Place.

C3 Yeah, there was a kid there and he was how you say drinking (like a cow from a trough) and $I$ asked them what he said was doing and they said they owned it and my God they run over the hill and the kids theya play de louda music.

(1.0)

P4 They're playing roudy music are they.

C4 Uh-hu (1.5) and I tella you they make so mucha noise.

$\rightarrow$ P5 Okay, and this is un two thirty one Upland Place.

C5 Yeh.

(10)(Nelsonville/*2/1978/01-51-18)

Pl Emergency Centre.

(1.0)

C1 Please, can I have help (0.5) the Prince Edward.

P2 What, where to?

C2 Mennoland, Now, I'm hiding in the closet I can't get out.

P3 What's the problem. How come you're hiding in the closet.

C3 I'm a mess. Look if I come out he's going to shoot me.

$\rightarrow$ P4 Okay what's the address there.

(Note: caller spoke softly)

(11) (Nelsonville/*6/1978/02-58-42)

P1 Dispatch.

C1 Yeh, I'm calling ah about a complaint um, we're at the Fun Club in Stonetown.

P2 What?s the name of the club's name.

C2 Fun.

P3 In Stonetown?

C3 Right, it's across the street from the Stonetown Hotel.

P4 Yeh.

C4 Well I'm a member and we went to the ( ) to this golf tournament right and um and they were told to leave at a certain time and they're completely drunk and I can't get them out of here and they told me go and call the police and I told them and warned them for the past two hours that they were to leave and/
C5 Yeh, and I can't get rid of them and they're starting to get bad language and I'm the only woman here and my husband said ((voice had trailed off))

$\rightarrow$ P6 Alright, who am I speaking to please.

(12) (Nelsonville/*59/1978/16-06-03)

C1 Yeh well I'm not// going to have 'em come here.

P1 Police fire and ambulance.

C2 Yes uh is this the police.

$\mathrm{P} 2$ Yes it is.

C3 Um I think I have what you call an um emergency call. I my daughter this morning said somebody gave her a pill? and she brought me the pill?

P3 Uh-hu.

C4 Now I have had speed long time ago okay? and to me it tasted like speed. I don't know I might be wrong but I don't think the kid in the area should be passing pills around to any of the little kids.

(2.0)

P4 Well how old's you daughter mam.

C5 My daughter?

P5 Yeh.

C6 Five.

$\rightarrow$ P6 Can I have your name please?

Notice, then, that in each case the specified police questions, with the partial exception of (3), have nothing specifically to do with marital problems (4), a party on a golf course (5), kids being beaten up at a swimming pool (6), making a lot of noise (9), the possibility of a shooting (10), bad language and being the only woman there (11), or age (12). But just in that way they can be heard as addressing the whole of what has gone before, namely the complaint-delivery. (While six of the eight questions here are preceded by 'Okay' or 'Alright' it is not by virtue of these objects alone that the whole complaint is heard to be accepted, since they may simply be heard as acknowledging receipt of the information in the immediately preceding turn (cf. Coulthard and Ashby, 1976: 85-88 on 'markers'.) That is, each of these questions or each receiptmark-plus-question invokes and thereby 'accomplishes' (Garfinkel, 1967; Sacks, 1976: G6) an order of call-organization grosser than turn-by-turn organization, namely that as a sequence of work tasks. ${ }^{4}$ Far from their off-the-subject character

${ }^{4}$ These cases then provide an example of what Eglin means by the 'instructional' character of the relationship between a sequential-linguistic object (an interrogative in a particular position, for example) and the action its speaker performs or activity its speaker accomplishes in uttering it there (Eglin, 1980a: Chapter Two; 1980b). 
being cause for caller complaint, callers answer them and subsequent questions readily, indicating thereby an orientation to the business at hand as one engaging them in their identity as 'citizen' visa-vis their interlocutor as 'police' (Maynard and Wilson, 1980: 301-302; Zimmerman, n. d.: 24; Schegloff, forthcoming (ms.): 25-26; Watson, forthcoming a (ms.): 24-26). Also, in not being questions that 'raise questions' about the caller's story, the specified police questions can be heard to accept it. This probably depends in part on some general interactional preference for agreeement or acceptance (Atkinson and Heritage, 1984: Part II see papers by Pomerantz, Davidson, Drew).

(b) Determining organizational relevance and seriousness.

If the police are going to send a car they need to know where, and precisely where; people do not like police calling on them by mistake. Indeed callers anticipate this by standardly offering an address in opening turn. If the police are going to keep in contact while the event develops or need to get in touch with caller quickly, then they need the caller's telephone number. If they are to know who they are dealing with for future reference they need the name.

And if they are to know whether the complainable is really police business, if so how many police cars to send, and how quickly to send them, they need to know what sort of, and how serious, an incident this is, where, indeed, caller may not know what precise details to give and so needs to be asked. See P4 in (9), P4 in (12) and the indicated turns in the following extracts.

(13)(Nelsonville/*2/1978/01-51-18)

P11 Okay what room are you in in the Prince Edward.

C11 ((Evidently talking to someone at the Prince Edward while also on the phone to the police)).

No, when they come through the back door if they and walk into the pantry I'll be hiding in there, they're out to the front right now and he's armed.

$\rightarrow$ P12 He's armed? is he.

(14) (Nelsonville/*20/1978/04-06-51)

P6 Yeh, Rutherford. What's the problem there sir.

C6 See this car parking there in my own parking space, my my wife came in and couldn't park in my own parking space.

$\rightarrow$ P7 Oh, it's a parking complaint is it.

(15)(Nelsonville/*6/1978/02-58-42)

[see extract (11) which is the beginning of this call] $\rightarrow$ P11 Approximately how many people are there who won't leave, do you know, approximately.

C11 Approximately about twenty, thirty and I, I've tried all my best and I can't get rid of them and they're not listening to me. The only thing I can do is call the police.

P12 Alright, do you have a phone number there.

C12 Yes, six two four, nine. eight five seven.

P13 Okay, we'll be there.

(16)(Nelsonville/*9/1978/05-26-45)

C2 Okay, my husband lives at six two one Smith Avenue and I think he's getting some guns to come over here and maybe do a little bit of murder or whatever and he's serious, so I think you'd better get the police over there right away. Six two one Smith.

$\rightarrow$ P3 Okay mam, did he phone you about this?

C3 No, I phoned him and he said that he was on his way over here and I just talked to my daughter and she said he's got the guns out and I live at three, nine, one Monarch, apartment six. . . . . ((address, name and phone number gathered)). . .

P9 Okay mam, we'll send someone around there, okay $=$

C9 = Okay right away because he's going to be leaving,// okay.

$\rightarrow$ P10 Okay*. Did your daughter phone you about this?

C10 Well I was talking to him and my oldest daughter is twenty-one and I just talked to her now and she says he's gone rangy-tangy so ((tails off))

P11 Okay we'll send someone over there okay?

(17) (Nelsonville/*12/1978/22-21-23)

C2 Yeh, ther's um, I'm not quite sure what's going on but this guy's carrying a girl and a lot of them seems to be really out of it and they're acting really strange and that down at, uh the (Miligrave).

P3 At where?

C3 Jones Street, across from the Miligrave home.

P4 In the Jones Park?

C4 Yeh, right in there. It seems that ther's one girl who's, uh, out of it. Like she's he's carrying her.

(4.0)

$\rightarrow$ P5 Okay, does does she seem to be struggling with him or ((trails off))

C5 I don't know. She the way he's carrying her it seems that she's really like uh, her body's limp.

P6 Uh-hu. Okay, the-we'll send someone up. What is your name?

(18) (Nelsonville/*28/1978/00-51-19)

P1 Police fire and ambulance.

C1 Police, I want the police.

P2 You have the police. 
C2 Oh, well could you send the police to four fifty one Jones. The kids are alone the mothers out and they're making a racket.

(1.0)

$\rightarrow$ P3 Just a noise?

C3 Yeh, well uh I guess the one boy's locked out, his sister won't let him in and he's yelling and screaming.

P4 Okay that was four fifty one?// Jones.

C4 Jones*, yeh.

P5 Can I have your name please.

C5 No, I'd rather not give it.

P6 Okay, we'll see what we can do.

C6 Okay, bye-bye.

P7 Bye.

(19) (Nelsonville'/*32/1978/01-33-15)

$\mathrm{D}=$ Dispatcher

P1 Emergency centre

C1 Hello uh my name is John Henry. I'm the sales manager for B Construction. We have ah ah rooming house at sixty South Street, six zero and I just got a phone call from one of the tenants who said another one of the tenants is drunk, and assaulted him and now has a twenty-two rifle rifle?, and uh he's very much afraid?

P2 Okay, it's sixty South Street.

- - - - - ((data omitted $))--.--$

C37 And then he said that guy is crazy and then he just started telling me I had to get over there right away, I had to get over there right away.

D10 Yeh, okay, okay. We are on our way um, I'll just keep you on the line uh for a few minutes. (1.0)

- - - - ((data omitted $))-\ldots$

$\rightarrow$ D15 So he hasn't actually threatened but he did assault, he assaulted your friend.

C46 Uh, listen, all I know is what I heard, I only talked with the man for about thirty seconds.

D16 Okay, it's important that we know whether he's threatened anybody with the gun or not sir.

C47 Well the Hamburger, the person who thought he was threatened said something to the effect of that he was being the guy was trying to kill him.

(4.0)

D17 So you're not really sure whether he does have the gun or not sir.

C48 I'm absolutely unsure of everything at this stage.

(2.0)

D18 Okay, sir.

C49 I just got woken out of bed with a phone call and I feel I've described it fairly closely.

D19 [ Okay, hold the line okay?

P36 Okay, we'll just keep you on the line.

C50 Okay.
(20) (Nelsonville/*37/1978/time missing)

P1 Emergency?

C1 Uh, yes could you please senda cruiser down to three seven four South Drive apartment two in Oldtown.

P2 Three seven four South? Drive.

C2 Yes, apartment two.

P3 Number two, what's the problem there.

C3 I wanta lay an assault char charge on a twelve year old boy.

$\rightarrow$ P4 You can't, you'd have to see a justice of the peace you can't lay a charge with a police officer.

C4 With, well what can I get the police to do because this twelve year old boy just uh slightly strangled my five year old nephew.

$\rightarrow$ P5 I see okay, that's a juvenile complaint.

C5 Yes.

P6 Allright I'll send somebody and who am I speaking to.

Finding out whether an anticipated assault involves a weapon $(13,19)$, that a complaint is one of a parking violation (14), how many alleged culprits are present (15), whether an anticipated assault was pre-announced by the expected assaulter or communicated by a competent witness ( 16 - notice the caller's attention to this via her reference to her daughter's age in $\mathrm{C10}$ ), whether an assault has occurred or is in progress (17), whether something more than a noise disturbance is involved (18), whether a juvenile or adult is involved $(20)$ - these questions are of the sort required to determine the relevance, seriousness and proper administrative categorization (Errington, 1973: 48-54) of the call as a police matter, and to fill out the form which the police phone-person will pass on to the dispatcher for relaying information to the patrol cars. As with the questions that doctors massively and routinely ask, their purpose is a technical one directed to the performance of a task (Cicourel, 1975; Jefferson and Lee, 1981).

The organizational basis for assigning relevance and seriousness has been explicated in a number of ethnographic studies in and around police communications rooms (see, for example, Reiss, 1971: 4-15, 70-88; Errington, 1973: 63-92; Rubinstein, 1973: 21-22, 73-87; Shearing, 1974; Wideman, 1978; Manning, 1979; Antunes and Scott, 1981). Some of their findings bear on the issue of the 'persuasive' power of police questions and we accordingly review them before returning to our own sample of cases.

According to the professional dominance thesis service-providers not only (re-)formulate serviceseekers' troubles at the latter's expense, but exert 
control by screening complaints at or subsequent to the point of entry and rejecting unwanted cases (for example, Weiss, 1973). Some studies of calls to the police, for example, focus attention on calls which do not result in the dispatch of a patrol car. Thus Shearing (1974) directs his analysis of the police dispatch decision to the $18 \%$ of his large sample of calls where no dispatch is made.

However, as with the $87 \%$ of patients' 'questions' that are answered by West's (1983: 89) doctors, it remains true that in $82 \%$ of Shearing's cases a car is dispatched (despite officers' expressed unwillingness in some cases). And similar percentages are reported for Detroit and St. Louis in 1968 by Bercal (1970: 682-684). ${ }^{5}$ For the decision is bound by a formal rule to dispatch a car in response to every citizen request for assistance (see also Rubinstein, 1973: 75; cf. Antunes and Scott, 1981: 174). The formal rule itself is based, presumably, on the fear of complaints and civil litigation against the police for not acting should the consequences be serious (Antunes and Scott, 1981: 177), and on the commonsense understanding that the call's being made itself indicates a probably valid problem (Bittner, 1974: 32; Reiss, 1971: 13). ${ }^{6}$

From the complaint officer's point of view the formal requirement translates into the question "can $I$ in this particular case, risk not dispatching a patrol car?" (Shearing, 1974: 80). When sergeants

${ }^{5}$ This is so if we assume, as seems reasonable, that Shearing's "calls reporting trouble. . .received. . directly from citizens" (1974: 80 ), which excludes calls received "indirectly via police divisions" $(80)$, correspond to Bercal's "calls resolved without referral" (1970: 683-684) which excludes calls referred to another government agency, those referred and/or transferred to another police bureau and those referred to a private agency. The proportion of this population of complaints which did not result in the dispatch of a patrol car is then $18 \%$ for Shearing's 'Canadian police department', $19 \%$ for Detroit and $15.5 \%$ for St. Louis. Bercal does not provide the pertinent breakdown for New York, but gives only the global figure: that is, of all calls received, $40 \%$ were handled without dispatching a patrol car. Thus Rubinstein's (1973: 76, fn. 5) citing of Bercal's global figures for Detroit $(36 \%)$ and New York $(40 \%)$ is potentially misleading. For a more detailed breakdown of the combined figures for three U. S. cities see Antunes and Scott (1981: 172).

${ }^{6}$ Compare the cognitive orientation and organizational context in terms of which psychiatric emergency teams in a regional community mental health clinic in Southern California decide which calls to service (Emerson and Pollner, 1978). were removed from the police bureau studied by McCleary, Nienstedt and Erven (1982) the ratio of dispatches to calls received increased, since "dispatchers lost this most important source of protection" (369) from the consequences of wrong decisions. They would now send "an officer to the scene of a call without questioning the call's validity" (369; see also Errington, 1973: 47, below, and Rubinstein, 1973: 75 on the similar use of corporals and lieutenants respectively). Similar considerations may be behind Maxfield's finding that "when the San Francisco police shifted from sworn personnel to civilian complaint clerks and dispatchers, the average number of patrol cars sent in response to citizen calls increased substantially, while the number of calls 'handled' over the phone declined sharply" (Antunes and Scott, 1981: 178-179, fn. 13).

However, McCleary et al also report data from interviews with dispatchers (not from observation of actual cases) that support Shearing's claim that in cases judged to be unworthy of police action, rather than test the rule, dispatch officers try "to persuade the caller of the triviality of the trouble in the hope that he will retract the request for police intervention" (Shearing, 1974: 84) and "to convince the caller of the uselessness of reporting the theft, and thereby encourage him to withdraw his report" (83; also Errington, 1973: 90). ${ }^{7}$

We find little or no evidence of 'persuading' or 'convincing' in our much smaller corpus. On the contrary we find that the police do accept a wide range of complaints, many not obviously within their legal mandate, and send someone to see (Bittner, 1974: 30). We have cases in which police were sent not only to apprehend the "two boys beating up on the little kids" at the pool (6), but to investigate at the priest's request the problem of neighbouring pigeons fouling the interior of his church (Nelsonville/*64/1978/11-48-53), and to respond to a homeowner's complaint about her

\footnotetext{
7 "No record is kept of calls that do not become an official police matter" (Errington, 1973: 26). "Any official crime. . .must begin with a 'service call', but not all 'service calls' result in an official crime. If a call for police assistance does not result in the dispatch of an officer, the event is not a 'service call'. This is an important point because, clearly, a police department can increase or decrease its official crime rate by increasing or decreasing the likelihood that a call for assistance will result in a dispatched 'service call"' (McCleary et al, 1982: 367).
} 
neighbour's newly mown "grass lying on my driveway" (Nelsonville/*71/1978/10-29-22).

Turner (1969) suggests that in deciding to respond to such calls the police are mindful of the time of the call (notice that the three preceding cases occurred from late-morning to mid-afternoon, that is, at 'slow' periods), the availability of officers and the possibility of valuable public relations work. Shearing (1974: 82) notes the "perceived 'busyness' of the dispatchers" as a relevant criterion.

Although there is no space to display the data here, we have cases in which police accept a previous caller's subsequent avowal that there is now no problem ("He's gone over to Ronnie Laing at forty-eight ... so he won't bother me rest of night" - Nelsonville/*34/1978/00-47-25), pursue a problem in the absence of the original caller (sending a cruiser in response to a woman's sobbing plea though a man is now on the line denying there is any trouble - Nelsonville/*36/1978/01-32-10), and order a thirdparty caller to take action until help arrives (to go attend a vomiting boy in the neighbouring yard until the ambulance arrives - Nelsonville/*39/1978/no time given ).

The issue as to whether, in assessing the organizational relevance and seriousness of callers' troubles, the police so formulate the complaint as to attempt to persuade the caller that no action is required, can be briefly addressed by examining some of the cases presented above (extracts [13][20]). In (14), (18), (19) and (20) the specified questions incorporate formulations of the gist of the talk so far, and are followed by the decisions of the caller confirming or disconfirming the formulation. "Formulations and decisions therefore comprise an adjacency pair type" (Watson, forthcoming a (ms.): 28; Heritage and Watson, 1979. 1980). For police interrogations the "policeman can use the preference for confirmation of formulations as a resource for persuading [the suspect] to 'buy into' the officer's description" (Watson, forthcoming a (ms.): 29), such that disconfirming the formulation becomes an accountable matter. But as suggested in (AI) for the case of identity and activity descriptors, in calls to the police the informational relevance of particular formulations is rather different from what it is in police interrogation and courtroom examination (see also Hayduk, 1976). Callers are not suspects. Their stories are not invited but volunteered. They initiate the encounters, not the police. Moreover, the police are under a strong constraint to respond. Therefore, although callers' answers in (18) and (19) partially disaffiliate from the preceding police formulations, and although callers provide partial accountings for those disaffiliations, the kind of information they provide or try to provide is that which conveys the police relevance of the complainable. Rather than persuasion or conflict there is joint orientation to a specification both of the trouble as a police matter, and of its relative seriousness and urgency. The callers' acceptance of the police formulations in (14 - the acceptance is not shown) and (20) seems quite unproblematic.

This again raises the question of service-seekers' 'resistance' to professional 'control'. While this is to be the subject of a further paper let it be noted here that in medical consultations the use of questions to produce gist formulations is different again from that in calls to the police. Commensurate with the typical discrepancy in medical knowledge between doctor and patient, but also with an anticipated career of contacts, formulation-bearing questions are put to use by doctors to "teach patients how to talk about their illnesses" (Hughes, 1982: 370; also Anderson, 1981: 10). Scheff (1968: 15) observes the same procedure in his psychiatric interview but redescribes such teaching as "subtle manipulation" in the interests of nefarious medical control. What seems plain enough, however, is that when patients do ask 'questions' they are almost always answered, that a patient may successfully ask as many 'questions' as the doctor (West, 1983: 88-89) if she/he wishes, that there are more ways of controlling topic development in institutional interaction than asking questions could (Turner, 1976: 240; Sharrock, 1979: 142; Atkinson and Drew, 1979: 50; Watson, forthcoming a (ms.): 23-31), that there are good grounds for believing that service-seekers' 'passivity' is selfinduced either from simple compliance or inhibitory anxiety "but that were they to attempt talking up they might find that acceptable enough and productive of desired responses" (Sharrock, 1979: 146; Garfinkel, 1967: 69-70). This last point can be illustrated for the police data by the extracts considered in the next and last part of this section of the paper.

\section{(c) Moving to the disposition (or opening up the closing)}

Consider the indicated questions in (21) and (22). In (21) caller has already delivered the complaint, which turns on his fear of being beaten up that night by his flat-mate (who is also his brother), and the police phone-person has gathered the usual 
facesheet information, the last item of which is the phone number (C16). Similarly, in (22) caller has reported seeing a man wearing no pants by the highway as he (the caller) was driving home from work, and facesheet data have been acquired finishing with the address ( $\mathrm{C} 9$ ). Notice, however, the different courses of the calls from there to their endings.

(21) (Nelsonville/*3/1978/01-56-09)

C16 two three four seven six five four.

P17 Okay, and how long do you think he'll be before he gets back.

C17 A:h, it's a hard time to say. It's like uh, the guy, he's gone all crazy tonight and he just went to walk his girlfriend home right $=$

P18 uh-hu

$\mathrm{C} 18$ = so I, I don't know when he'll be back and I don't want to get beat up tonight, I'm kindof a chicken but the thing is that ah I don't want him to come back here and wreck the place, that's what he's like.

$\rightarrow$ P19 Do you want uh to call us when he comes back or do you want to see us ((trails off))

C19 I don't know how long my friends are going to be here to help me.

(1.0)

P20 Yeh

(3.5)

C20 Okay, well, I'll call you when he gets back okay?

P21 Okay, fine.

C21 Okay bye.

P22 Bye bye.

(22)(Nelsonville/*79/1978/17-34-00)

C9 One thirty-one, unit two, Point drive?

P10 Point drive. You don't wanta see an officer do you?

C10 What's that?

$\rightarrow$ P11 You don't wanta see an officer, you just want to report it?

C11 Well I just don't want some weirdo like that walking around eh?

P12 Oh I see. Okay what's your phone number please?

C12 Nine eight seven three five nine one.

P13 Do you believe he's intoxicated or something//? sir.

C13 Well he about a month ago I seen it eh?

P14 Yeh.

C14 And then when I got home here I don't know why I didn't phone but then I seen it again last night again and I thought god don't, I'm going to phone you know, you know?

P15 Oh I see. He's still there now eh?

C15 Well he should be but.

P16 He should be there now. Okay we'll send an officer around to check it out okay sir?

C16 Yeh okay.
P17 Thank you.

C17 Bye.

P18 Good-bye.

These two police questions, P19 in (21) and P11 in (22), are superficially comparable, allowing for their quite different syntactic shapes (Labov and Fanshel, 1977: Chapter Three), to the 'either/or' questions by which, according to one representative expression of the professional dominance thesis, "the physician limits both the placement and content of possible patient responses" (West, 1983: 90). Space considerations prohibit reproducing West's data extract. Suffice it to say that the 'placement limitation' she apparently infers from the fact that the 'or' option in each of her two displayed cases overlaps the patient's reply, actually results from the patient overlapping (indeed, in West's own terms, 'interrupting') the doctor by anticipating the possible completion points of his questions. That the patient's answers are selected from the options given by the doctor she interprets as 'content limitation'. But it is not clear, given that the patient does not attempt to say anything else, why such occurrences should be called 'limitation' (Sharrock, 1979: 140-143). For, as Turner and others have argued, in references already cited, when service-seekers do wish to add information they have resources to do so. Again, West's attention to the function of formal categories is at the expense of a consideration of the substance of the questions.

While, from West's data, it is possible only to guess at the substantive medical significance of the doctor's questions, we are in a better position with the police data. For the options on offer are indeed the dispositions police can make - to take a report, to send an officer, to be available for a later call. Rather than limiting caller's options the police are providing options, and providing them for caller's selection. And if there are any grounds for supposing that the either/or format contributes to a preference for the least police-active disposition - 'contributes' because that disposition is indicated rather more strongly by the negative assertion plus question tag in P10 in (22) - it does not prevent caller from selecting the other option, as indeed is the case in (22). As for (21), are we to say that because caller chose the 'call back' option that he was constrained by the 'either/or' format of P19 and that the phone-person deliberately employed that format so to constrain him (plus the noncommittal 'Yeh' and the unfilled pauses)? What would be our evidence for that? 
We are on somewhat firmer ground in noticing that what both these questions do in terms of the sequence of police work tasks is to invoke the overall structural organization of the call and open up the transition from the information-gathering, question/answer sequence to the settling of the disposition as a vehicle for the call's closing (Schegloff and Sacks, 1974). While an either/or format seems a useful device for bringing matters to a close by providing the participants with an opportunity to settle on a single item of last business, it is after all a device for interlocutors' use, not a dictator of their actions, as the reopening of business at $\mathrm{C} 11$ and P12 in (22) well shows. (Readers intrigued by the two (rare) appearances of 'Oh I see' should consult Heritage (1984a) for resolution). As we have argued for interruptions, for certain facesheet questions and for formulation-bearing questions, enumerating the distribution of either/or questions based on grammatical or sequential criteria will not recover the interactional organization of the talk, not the tasks being performed, not the activities conducted, and therefore it is an unlikely method for assessing the presence of professional dominance.

\section{Task Performance: A Summary}

"It appears that the 'essential concern' of a Service Supplier is the dispatching of a task, and whatever activities, information, etc., are critical thereto" (Jefferson and Lee, 1981: 416).

Together with other studies of calls to the police (Sharrock and Turner, 1978; Zimmerman, n. d.) this one reveals a pattern of interactional organization in which, routinely but not invariably,

(I) an opening identity and recognition sequence (Schegloff, 1968, 1979) is followed by

(II) a complaint/response adjacency pair, the two parts of the adjacency pair being separated by

(III) an extended insertion sequence comprising an 'interrogative series' (Zimmerman, n. d.), with the call culminating in

(IV) a closing sequence.

This pattern, its variations and its features of orderliness, 'asymmetry', mutual identity and the rest are the massive co-produced achievement of the parties to each and every call (Garfinkel, 1967; Schegloff, 1981: 89). That achievement derives from the parties' mutual orientation to

(a) the occasion of the call as one in which talk is directed to the performance of a technical, work- related, service-seeking-and-supplying set of tasks, tasks which establish

(b) the relevance of co-identification in terms of a particular pair of identities (here, 'police'/'citizen') and

(c) a characteristic distribution of speakers' rights to turns, turn types and turn sizes.

We suggest that in trying to account for the observed features of any kind of professional service encounter or institutional interaction, be those features the 'distribution' of overlaps, 'interruptions', 'questions' or whatever (Drew, 1985: 141-142), observers should address such members' orientations as these before importing observer-defined external variables such as gender, race, class or professional power. Not that, say, every action performed in a medical consultation or call to the police will necessarily require the parties to address each other in terms of the specific identities attached to those settings or occasions (Turner, 1972; see also (23) below).

Many of the 'members' methods' by which the parties concert their actions will almost certainly be general to talk as such (Sacks et al, 1974; Schegloff et al, 1977), others perhaps general to professional service encounters as such. It is the observer's task to discover when and how the parties invoke and accomplish those particular identities in the course of interacting (Schegloff, forthcoming; Heritage, 1984b: 280-290).

Here, then, is a summary list of some of the ways parties do a call to the police display their orientation to task performance, co-identification as police-and-citizen and the distribution of speakers' rights. The list is restricted to matters relevant to the themes of this paper; discussion of other aspects can be found in Sharrock and Turner (1978) and Zimmerman (n. d.).

(I) When calling the police, in contrast to calling a friend or relative, callers frequently, not to say standardly, give their address in opening or second turn ((4), (5), (6), (9), (10), (11), (18), (20)). Whether this is to give the police a means of immediately recognising the kind of trouble-call this is going to be ('this is X bank', 'Y hotel', etc.) or of simply telling them where to send the patrol car, or both, it is clearly 'recipient-designed' (Schegloff, 1972; Sacks et al, 1974: 727), moreover designed for that kind of recipient who will recognise its task-based relevance, namely the 'police'. 
The mere giving of an address, then, orients to, invokes and accomplishes the business of the encounter as servicing a trouble and the complementary identities of the parties as police and citizen. As such it exhibits cooperation and collaboration in a mutual endeavour, not a disposition to negotiating a bargain with a competitor.

(II) In contrast to story-telling in conversation, callers to the police frequently do not preface their complaint-stories with components designed to characterise the upcoming story, nor do they request permission to tell the story in order to suspend the relevance of turn-transition till they have finished (Sacks, 1974). They simply (at least for the purposes of this point) deliver the story ((5), (9), (18), (19)) and recipient does not come in at turntransition relevant places. The possibility of that mutually-coordinated accomplishment is founded on the parties' mutual reliance on joint orientation to the relevance of a particular phase of the task structure of the encounter with its associated identities and rights to talk. Of course, with only 'trouble' to look for, recipient may fail to identify the end of the complaint-delivery; this may account for the more than a few 'trailings-off' that occur in this position. What appears, then, to casual inspection as police indifference in those cases can be given instead a turn-organizational explanation.

(III) Point (II) may well be related to a further contrast with conversation in that there is no expectation in calls to the police that first stories will be followed by recipient-told second stories. Indeed, for complaint-stories in conversation "the classical format for dealing with somebody's complaining about their problems is to introduce your own" (Sacks, 1969 (8): 6). This manifestly does not occur in calls to the police, nor, we venture, standardly in other professional service encounters or forms of institutional interaction (Cuff and Francis, 1978; Jefferson and Lee, 1981; Watson, forthcoming a, b). Additionally, we may note the noticeable absence of 'newsmarks' ('Oh, really?') in recipients' responses to the complaint-stories, a characteristic further distinguishing them from conversation (Heritage, 1984a: 336, 339-344). The point is that it is in talking and witholding talk in just these ways (Schegloff, 1981: 89) that the speakers accomplish the talk as service-interaction. Notice what happens in (23) when an excursion into conversation occurs (and compare the virtually identical case collected by Schegloff, discussed by Sacks in his lectures and reproduced in Benson and Hughes (1983: 167)).
(23)(Nelsonville/*64/1978/11-48-53)

P9 Okay, did you want to see the officer about this one.

C9 Yeh I'd like to. Who's this please.

P10 Uh Mary in dispatch.

C10 I know you.

P11 Do you.

C11 Yeh. Oh I have a line on all these. I I'm the chaplain of Forbes Greenwood so I check all you kids here too.

P12 Oh do you ((laughs)).

C12 In a nice way. Especially that English kid.

P13 ((laughs)) Yah, Mabel?

C13 Well she was in my parish in Big city.

P14 Oh was? she.

C14 She was then and when I moved out of there she moved.

P15 Well she must like you then.

C15 Give or take a little.

P16 Yes/

C16 But I would like something done because this is an awful dirt.

P17 Okay.

Recipient's newsmarks (P11, P12, P14), laughter (P12, P13) and commentary (P15) all mark this stretch, from half-way through $\mathrm{C} 9$ to $\mathrm{P} 16$, as conversation, not service-interaction; ${ }^{8}$ in $\mathrm{C} 16$ caller reintroduces the reason for the call - the problem of the pigeons in the church.

(IV) Having delivered their complaints callers, as we have seen, routinely submit to being questioned and to having their troubles formulated and reformulated. Together with their own occasional tentative formulations

\footnotetext{
${ }^{8}$ Antunes and Scott (1981) complain that for the 26,000 calls observed in their study, operators "generally were not expansive in their interactions with citizens" (175), frequently did not indicate their appreciation of citizens' efforts in calling (176), but were, "typically, abrupt" (177). They propose, without evidence, (i) that this detracts from the public's image of the police, and (ii) that professionalization of phone operators is the remedy. However, they do not differentiate between victim-initiated and on-behalf-of calls (Errington, 1973: 44; Sharrock and Turner, 1978; Eglin and Wideman, 1979). Interactional analysis of hard, conversational data suggests that "sufferers of a trouble do not welcome the 'humanizing' of a Service Encounter" (Jefferson and Lee, 1981: 417), preferring that service-providers deal with their complaints and not with them.
} 
- 'it's not really a total emergency sort of thing' (C3 in (6))

- 'Um I think I have what you call an um emergency call' (C3 in (12))

- 'Uh say ah just a little complaint' (C3 in Nelsonville/ *75/1978/09-04-03)

- 'It might not seem important but, it was a Union Jack (1.5) and its importan to us' (C9 in Nelsonville/*48/ 1978/06-35-00)

this reveals callers' orientation to the 'candidacy status' of the complainable, and their expectation that the recipient will assess its relevance and seriousness. Again this accomplishes the service character of the interaction and the professional/ lay distribution of identities. Far from evidencing a power struggle this 'realises' legitimate authority (Watson, forthcoming b). Conversely, when caller says in opening turn, 'Please, can I have help (0.5) the Prince Edward' (10), or, as in (24)

(24)(Nelsonville/*36/1978/01-32-10)

Pl Emergency Centre

C1 I need the police here at one one six F Upland Place.

P2 One one four/

C2 Quick ((shouted))

issues an opening demand ( $\mathrm{C} 1$ ) followed by an interruptive shouted imperative $(\mathrm{C} 2)$, it is clear that there is a distribution of rights and obligations that operates in favour of the caller (Sacks, 1972a). But it is nevertheless one that attaches to caller as an incumbent of the identity-category '(lay) service-seeker' vis-a-vis a '(professional) service-provider', and not just any service-provider, rather that kind that responds to unspecified trouble at the ring of a telephone, namely the police.

Rather than citizens entering an arena of unwanted power-conflict when calling the police, they call for the exercise of police power. As Bittner (1974) has powerfully argued, the criminal-legal mandate of the police aside, citizens call on the police for the exercise of just that capacity they uniquely have, the capacity to use force, to exercise power, to take command in emergency situations of civil life. This expectation is the basis of that 60's joke, 'Next time you're in trouble, call a hippy'. It is the basis for the expectation that police will question callers as to the formulation of the complaint, will propose re-formulations and that callers will comply. But at the same time it provides for the expectation that they (the police) will come at once when called for, if necessary with no account being given (as in the continuation of (24)) or an account of the most minimal sort ('Marital' in (4)). And, as in these cases, they do go.

(V) As for questions, they are like the members of a church: if you want to know what they are good for, the last thing you do is count them. For, as we have seen, though they all ask for 'information', questions are put to quite different interactional uses in the calls - accepting the complaint-delivery, determining organizational significance, opening up the closing. From their responses to them, though not analysed here, it is clear that callers treat them accordingly - where necessary, as in C11 in (22) for example, 'Well I just don't want some weirdo like that walking around eh?', using a variety of disaffiliating-cum-disagreeing devices ('Well' (Pomerantz, 1984: 72ff)), 'weirdo', question-tag) to re-direct the prior pre-closing move in order to keep the call alive and get the police preference for merely reporting the incident reassessed. That is, both police and callers orient to the questions as task-performing devices, such that disagreement with a disposition-proposing-question is quite consistent with compliance with questions performing other tasks. Generalizing conflict from single cases is thus a dangerous game, since not all 'information-seeking' questions are cases of the same thing.

\section{Conclusion}

We made it clear at the beginning that the structural version of the professional dominance thesis was not in question here, just the interactional interpretation of it. Despite the growth of private policing, civil police authorities in Western societies enjoy a virtual monopoly of the use of civil force. Similarly, despite the proliferation in recent years of alternative 'medicines' the established profession of medicine dominates the provision of health care. But to acknowledge this structural dominance, moreover to allow that it structures the police/citizen or doctor/patient relationship is not to say that calls to the police or medical encounters are arenas of strategic interaction characterised by negotiation, conflict or struggle. To generalize a point of Sharrock's (1979: 136), what proponents of the interactional version of the PD thesis do is "make a genuine problem about the professionalclient relationship into an organizational problem for the examination of professional-client interaction" (see also Strong, 1979b; Conrad and Schneider, 1980; Anderson, 1981: 3). ${ }^{9}$ 
As the studies of West and a host of others show, professionals' 'verbal strategies of control' can be read into and out of the interactional specifics of professional service encounters. But the price of that reading is one of missing (a) how the 'factual data' - the questions, overlaps, 'interruptions', their asymmetrical distribution, the parties' identities as 'doctor', 'patient', 'police', 'citizen' - are the accomplished production of the collaborative, concerted work of the parties themselves, and of ignoring (b) the observer's own methodological work in translating these phenomena into indices of the exercise of professional power. We have tried in this study not to miss (a). It remains for a future study to examine (b).

${ }^{9}$ What we would rather say is that if it can be said that institutionalized inequality of power characterises one or other type of professional/client interaction then that is the ongoing product of the mutually concerted interactional work of the parties to each and every encounter (Maynard and Wilson, 1980: 317, fn. 31). Conversation analysis begins here to account for that fundamental sociological phenomenon, institutionalization. Giddens appears to appreciate this, citing as he does part of the analysis by Maynard and Wilson (1980) of a segment of courtroom sentencing talk to illustrate his theory of structuration (Giddens, 1984: 330-331; see also Eglin, 1980b: 131, fn. 8). But then he lets slip in externally-derived power in a by now familiar way: "However, it is noticeable that the sequence of talk does not follow the more 'democratic' rules that conversations between peers ordinarily display, and does directly reflect differential power. Thus the judge has the right to interrupt what the others say, to pose particular types of questions and to control the sequence of talk, which the others do not have, at least to the same degree" (Giddens, 1984: 332). But in the case at hand there are no interruptions, there is nothing special about the types of questions asked by the judge, and Giddens leaves out of account just that part of their analysis where Maynard and Wilson show how the Public Defender, in talking to sentence in response to the judge's questions, so develops and controls the topic as to reduce successfully the original charge from a felony to a misdemeanour. Gidden's theoretical reach is awesome, but its empirical application here, while partly right, seems also partly wrong.

\section{References}

Anderson, D. C., 1981: Abstractive and observational methods of educational evaluation in a dietetic clinic. Sociology of Health and Illness 3: 1-14.

Anderson, D. C. and W. W. Sharrock, 1979: Biasing the news: technical issues in 'media studies'. Sociology 13: 367-385.

Anderson, R. J. and W. W. Sharrock, forthcoming: Aspects of the distribution of work tasks in medical encounters. To appear in J. N. Schenkein (ed.), Studies in the Organization of Conversational Interaction. Volume 2. New York: Academic.

Antunes, C. and E. J. Scott, 1981: Calling the cops: police telephone operators and citizen calls for service. Journal of Criminal Justice 9: 165-180.

Atkinson, J. M., 1981: Review article: D. Downes and P. Rock (eds.), Deviant Interpretations. International Journal of the Sociology of Law 9: 101-106.

Atkinson, J. M. and P. Drew, 1979: Order in Court London: Macmillan.

Atkinson, J. M. and J. Heritage (eds.), 1984: Structures of Social Action: Studies in Conversation Analysis. Cambridge: Cambridge, and Paris: Maison des Sciences de l'Homme.

Austin, J. L., 1962: How To Do Things With Words. London: Oxford.

Benson, D. and J. A. Hughes, 1983: The Perspective of Ethnomethodology. London: Longman.

Bercal, T. M., 1970: Calls for police assistance: consumer demands for governmental service. American Behavioral Scientist 13: 681-691.

Bergmann, J. R., 1981: Frage und Frageparaphrase: Aspekte der redezuginternen und sequenziellen Organisation eines Ausserungsformats. S. $128-142$ in P. Winkler (Hrsg.), Methoden der Analyse von Face-toFace Situationen. Stuttgart: Metzlersche. 1982: Schweigephasen im Gespräch - Aspekte ihrer interaktiven Organisation. S. $143-183$ in H.-G. Soeffner (Hrsg.), Beiträge zu einer empirischen Sprachsoziologie. Tübingen: Narr.

Bittner, E., 1967: The police on skid-row: a study of peace keeping. American Sociological Review 32: 699-715. 1974: Florence Nightingale in pursuit of Willie Sutton: a theory of the police. Pp. 17-44 in H. Jacob (ed.), Potential for Reform of Criminal Justice. Beverly Hills, Cal.: Sage.

Black, D. J., 1976: The social organization of arrest. Pp. 52-78 in W. B. Sanders and H. C. Daudistel (eds.), The Criminal Justice Process. New York: Praeger. (Originally published in Stanford Law Review 23: 1087-1111, 1971).

Bogoch, B. and B. Danet, 1984: Challenge and control in lawyer-client interaction: a case study in an Israeli Legal Aid office. Text 4: 249-275.

Carlen, P., 1976: Magistrates' Justice. London: Martin Robertson.

Cazden, C. B., 1979: Language in education: variation in the teacher-talk register. Pp. 144-162 in J. E. Alatis and G. R. Tucker (eds.), Georgetown University 
Round Table on Languages and Linguistics 1979. Washington, D. C.: Georgetown.

Cicourel, A. V., 1975: Discourse and text: cognitive and linguistic processes in studies of social structure. Versus $12:$ :33-84.

Conrad, P. and J. W. Schneider, 1980: Looking at levels of medicalization: a comment on Strong's critique of the thesis of medical imperialism. Social Science and Medicine 14A: 75-79.

Coulthard, M. and M. Ashby, 1976: A linguistic description of doctor-patient interviews. $\mathrm{Pp} .69-88$ in $\mathrm{M}$. Wadsworth and D. Robinson (eds.), Studies in Everyday Medical Life. London: Martin Robertson.

Cuff, E. C. and D. W. Francis, 1978: Some features of 'invited stories' about marriage breakdown. International Journal of the Sociology of Language 18: 111-133.

Danet, B. and B. Bogoch, 1980: Fixed fight or free-forall? An empirical study of combativeness in the adversary system of justice. British Journal of Law and Society 6: 36-60.

Daudistel, H. C., W. B. Sanders and D. F. Luckenbill (eds.), 1979: Criminal Justice: Situations and Decisions. New York: Holt, Rinehart and Windston.

Di Pietro, R. J. (ed.):, 1982: Linguistics and the Professions: Proceedings of the Second Annual Delaware Symposium on Language Studies. (Advances in Discourse Processes, Volume VIII) Norwood: Ablex.

Drew, P., 1985: Analyzing the use of language in courtroom interaction. Pp. 133-147 in T. Van Dijk (ed.), Handbook of Discourse Analysis, Volume 3: Discourse and Dialogue. London: Academic.

Dunstan, R., 1980: Contexts for coercion: analyzing properties of courtroom 'questions'. British Journal of Law and Society 6: 61-77.

Edwards, A. D. and V. J. Furlong, 1978: The Language of Teaching. London: Heinemann.

Eglin, P. A., 1980a: Talk and Taxonomy. Amsterdam: John Benjamins. 1980b: Culture as method: location as an interactional device. Journal of Pragmatics 4 : 121-135.

Eglin, P. A. and D. B. Wideman, 1979: Calling the police: some aspects of the interactional organization of complaints in crime reporting. Analytic Sociology 2 (2): Microfiche.

Emerson, R. M. and M. Pollner, 1978: Policies and practices of psychiatric case selection. Sociology of Work and Occupations 5: 75-96.

Ericson, R., 1982: Reproducing Order. Toronto: Toronto.

Erickson, F. and J. Shultz, 1982: The Counsellor as Gatekeeper. New York: Academic.

Errington, B. G., 1973: Negotiating the Decision: What is a Police Matter. Unpublished master's thesis: University of British Columbia (Sociology).

Fisher, S., 1982: The decision-making context: how doctors and patients communicate. Pp. 51-81 in R. J. Di Pietro (ed.), Linguistics and the Professions. Norwood: Ablex.
Fowler, R., B. Hodge, G. Kress and T. Trew, 1979: Language and Control. London: Routledge.

Freidson, E., 1970: Professional Dominance: The Social Structure of Medical Care. New York: Atherton.

Garfinkel, H., 1967: Studies in Ethnomethodology. Englewood Cliffs, N. J.: Prentice-Hall.

Giddens, A., 1984: The Constitution of Society. Cambridge: Polity.

Gill, M., R. Newman and F. C. Redlich, 1954: The Initial Interview in Psychiatric Practice. New York: International Universities Press.

Groves, P. H., 1973: Lawyer client interviews and the social organization of preparation for court in criminal and divorce cases. Unpublished doctoral dissertation: University of British Columbia (Sociology).

Haberland, H. and J. L. Mey, 1981: Wording and warding: the pragmatics of therapeutical conversation. Journal of Pragmatics 5: 102-111.

Harris, R., 1981: The Language Myth. London: Duckworth.

Hayduk, L. A., 1976: Formulations in police work: some observations and related theoretical concerns. Canadian Journal of Sociology 1: 463-479.

Heap, J. L., 1979: Classroom talk: a critique of McHoul. Occasional Paper of the Project on the Social Organization of Reading Activites, Dept. of Sociology in Education, Ontario Institute for Studies in Education. (Forthcoming in Analytic Sociology?)

Heritage, J., 1984a: A change-of-state token and aspects of its sequential placement. Pp. 299-345 in J. M. Atkinson and J. Heritage (eds.), Structures of Social Action. Cambridge: Cambridge, and Paris: Maison des Sciences de l'Homme. 1984b: Garfinkel and Ethnomethodology. Cambridge: Polity. 1985a: Recent developments in conversation analysis. Sociolinguistics 15(1): 1-19. 1985b: Analyzing news interviews: aspects of the production of talk for an overhearing audience. Pp. 95-117 in T. Van Dijk (ed.), Handbook of Discourse Analysis, Volume 3: Discourse and Dialogue. London: Academic.

Heritage, J, and J. M. Atkinson, 1984: Introduction. Pp. 1-15 in J. M. Atkinson and J. Heritage (eds.), Structures of Social Action. Cambridge: Cambridge, and $\mathrm{Pa}$ ris: Maison des Sciences de l'Homme.

Heritage, J. and D. R. Watson, 1979: Formulations as conversational objects. Pp. 123-162 in G. Psathas (ed.), Everyday Language: Studies in Ethnomethodology. New York: Irvington. 1980: Aspects of the properties of formulations in natural conversations: some instances analyzed. Semiotica 30: 245-262.

Hughes, D., 1982: Control in the medical consultation: organizing talk in a situation where co-participants have different competence. Sociology 16: 359-376.

Jefferson, G. and J. R. E. Lee, 1981: The rejection of advice: managing the problematic convergence of a 'troubles-telling' and a 'service encounter'. Journal of Pragmatics 5: 399-422.

Johnson, T. J., 1972: Professions and Power. London: Macmillan. 
Labov, W. and D. Fanshel, 1977: Therapeutic Discourse: Psychotherapy as Conversation. New York: Academic.

Lacoste, M., 1981: The old woman and the doctor: a contribution to the analysis of unequal linguistic exchanges. Journal of Pragmatics 5: 169-180.

Manning, P. K., 1979: Semiotics and loosely coupled organizations. Revised version of paper presented at the annual meetings of the Southern Sociological Society, Atlanta, Georgia, April 1979.

Maynard, D. W., 1984: Inside Plea-Bargaining. New York: Plenum.

Maynard, D. W. and T. P. Wilson, 1980: On the reification of social structure. Pp. $287-322$ in S. G. McNall and G. N. Howe (eds.), Current Perspectives in Social Theory, Volume 1. Greenwich: JAI.

McCleary, R., B. C. Nienstedt and J. M. Erven, 1982: Uniform crime reports as organizational outcomes: three time series experiments. Social Problems 29: 361-371.

McHoul, A. W., 1978: The organization of turns at formal talk in the classroom. Language in Society 7: 183-213. 1979 Classroom talk: modulated acceptances of Heap. (Forthcoming in Analytic Sociology?)

McHoul, A. W. and D. R. Watson, 1984: Two axes for the analysis of 'commonsense' and 'formal' geographic knowledge in classroom talk. British Journal of Sociology of Education 5: 281-302.

Mehan, H., 1979: Learning Lessons: Social Organization in the Classroom. Cambridge: Harvard.

Merritt, M., 1976: On questions following questions in service encounters. Language in Society 5: 315-357.

Murdock, G., 1976: Youth in contemporary Britain: misleading imagery and misapplied action. Pp. 15-26 in D. Marsland and M. Day (eds.), Youth Service, Youth Work and the Future. National Youth Bureau, occasional paper. 1980: Misrepresenting media sociology: a reply to Anderson and Sharrock. Sociology 14: 457-468.

O'Barr, W. M., 1982: Linguistic Evidence: Language, Power, and Strategy in the Courtroom. New York: Academic.

Payne, G. C. F. and E. C. Cuff (eds.): 1982: Doing Teaching: The Practicial Managment of Classrooms. London: Batsford.

Pittenger, R. E., C. F. Hockett and J. J. Danehy, 1960: The First Five Minutes: A Sample of Microscopic Interview Analysis. Ithaca, N. Y.: Paul Martineau.

Pomerantz, A., 1984: Agreeing and disagreeing with assessments: some features of preferred/dispreferred turn shapes. Pp. 57-101 in J. M. Atkinson and J. Heritage (eds.), Structures of Social Action. Cambridge: Cambridge, and Paris: Maison des Sciences de l'Homme.

Reiss, A. J., 1971: The Police and the Public. New Haven: Yale.

Rubinstein, J., 1973: City Police. New York: Farrar, Straus and Giroux.

Sacks, H., 1969: Unpublished lectures. University of California, Irvine. 1971: Unpublished lectures. Uni- versity of California, Irvine. 1972a: An initial investigation of the usability of conversational data for doing sociology. Pp. 31-74 in D. Sudnow (ed.), Studies in Social Interaction. New York: Free Press. 1972b: On the analyzability of stories by children. Pp. $329-345$ in J. J. Gumperz and D. Hymes (eds.), Directions in Sociolinguistics. New York: Holt, Rinehart and Winston. (Reprinted in Roy Turner (ed.), Ethnomethodology. Harmondsworth: Penguin, 1974, pp. 216-232). 1972c: Notes on police assessment of moral character. Pp. 280-293 in D. Sudnow (ed.), Studies in Social Interaction. New York: Free Press. 1974: An analysis of the course of a joke's telling in conversation. Pp. 337-353 in R. Bauman and J. Sherzer (eds.), Explorations in the Ethnography of Speaking. Cambridge: Cambridge. 1975: Everyone has to lie. Pp. 57-80 in M. Sanches and B. Blount (eds.), Sociocultural Dimensions of Language Use. New York: Academic. 1976: On formulating context. Pragmatics Microfiche 1(7): F5-G8.

Sacks, H., E. A. Schegloff and G. Jefferson, 1974: A simplest systematics for the organization of turn-taking for conversation. Language 50:696-735. (Reprinted in J. N. Schenkein (ed.), Studies in the Organization of Conversational Interaction. New York: Academic, 1978, pp. 7-55).

Scheff, T. J., 1968: Negotiating reality: notes on power in the assessment of responsibility. Social Problems 16: 3-17.

Schegloff, E. A., 1968: Sequencing in conversational openings. American Anthropologist 70: 1075-1095. 1972: Notes on a conversational practice: formulating place. Pp. 75-119 in D. Sudnow (ed.), Studies in Social Interaction. New York: Free Press. 1979: Identification and recognition in telephone openings. Pp. 23-78 in G. Psathas (ed.), Everyday Language: Studies in Ethnomethodology. New York: Irvington. 1981: Discourse as an interactional achievement: some uses of 'uh huh' and other things that come between sentences. Pp. 71-93 in D. Tannen (ed.), Georgetown University Round Table on Languages and Linguistics 1981. Washington, D. C.: Georgetown. 1984: On some questions and ambiguities in conversation. Pp. 28-52 in J. M. Atkinson and J. Heritage (eds.), Structures of Social Action. Cambridge: Cambridge, and Paris: Maison des Sciences de l'Homme. (Reprinted from Pp. 81-102 in W. U. Dressler (ed.), Current Trends in Textlinguistics. Berlin: de Gruyter, 1978. Originally published in Pragmatics Microfiche, 1976.) Forthcoming: Between macro and micro: contexts and other connections. In J. Alexander, G. Giesen, R. Munch and N. Smelser (eds.), The Micro-Macro Link. Berkeley and Los Angeles: California.

Schegloff, E. A. and H. Sacks, 1974: Opening up closings. Pp. 233-264 in R. Turner (ed.), Ethnomethodology. Harmondsworth: Penguin. (Originally published in Semiotica 8: 289-327, 1973).

Schegloff, E. A., G. Jefferson and H. Sacks, 1977: The preference for self-correction in the organization of repair in conversation. Language 53: 361-382. 
Sharrock, W. W., 1979: Portraying the professional relationship. Pp. 125-146 in D. C. Anderson (ed.), Health Education in Practice. London: Croom Helm.

Sharrock, W. W. and D. C. Anderson, 1981: Language, thought and reality, again. Sociology 15: 287-293. 1982: The persistent evasion of technical problems in media studies: a reply to Murdock and McKeganey and Smith. Sociology 16: 108-115.

Sharrock, W. W. and Roy Turner, 1978: On a conversational environment for equivocality. Pp. 173-197 in J. $\mathrm{N}$. Schenkein (ed.), Studies in the Organization of Conversational Interaction. New York: Academic.

Sharrock, W. W. and D. R. Watson, 1984: What's the point of 'rescuing motives"? British Journal of Sociology $35: 435-451$.

Shearing, C. D., 1974: Dial-a-cop: a study of police mobilization. Pp. 77-88 in R. L. Akers and E. Sagarin (eds.), Crime Prevention and Social Control. New York: Praeger.

Strong, P. M., 1979a: The Ceremonial Order of the Clinic: Parents, Doctors and Medical Bureaucracies. London: Routledge. 1979b: Sociological imperialism and the profession of medicine: a critical examination of the thesis of medical imperialism. Social Science and Medicine 13A: 199-215. 1979c: Materialism and medical interaction: a critique of 'medicine, superstructure and micropolitics'. Social Science and Medicine 13A: 613-619.

Sudnow, D., 1965: Normal crimes: sociological features of the penal code in a public defender's office. Social Problems 12: 255-276.

Thorne, B., C. Kramarae and N. Henley (eds.), 1983: Language, Gender and Society. Rowley: Newbury.

Turner, Roy, 1969: Occupational routines: some demand characteristics of police work. Paper presented at the annual meetings of the Canadian Sociology and Anthropology Association, Toronto, June, 1969. 1972: Some formal properties of therapy talk. Pp. 367-396 in D. Sudnow (ed.), Studies in Social Interaction. New York: Free Press. 1976: Utterance positioning as an interactional resource. Semiotica 17: 233-254.

Wadsworth, M. and D. Robinson (eds.), 1976: Studies in Everyday Medical Life. London: Martin Robertson.

Waitzkin, H., 1979: Medicine, superstructure and micropolitics. Social Science and Medicine 13A: 601-609.

Walker, S. A., 1980: Extended review: The Language of Teaching. British Journal of Sociology of Education 1: 327-332.

Watson, D. R., 1981: Conversational and organizational uses of proper names: an aspect of counsellor-client interaction. Pp. 91-106 in P. Atkinson and C. Heath (eds.), Medical Work. Farnborough: Gower. 1983: The presentation of victim and motive in discourse: the case of police interrogations and interviews. Victimology 8: 31-52. Forthcoming a: Some features of elicitation of confessions in murder interrogations. In $\mathbf{G}$. Psathas (ed.), Interactional Competence. New York: Erlbaum. Forthcoming b: Doing the organization's work: an examination of aspects of the operation of a crisis intervention centre. In S. Fisher and A. Todd (eds.), Discourse and Institutional Authority: Law, Medicine and Education. Norwood: Ablex.

Weiss, R. S., 1973: Helping relationships: relationships of clients with physicians, social workers, priests and others. Social Problems 20: 319-328.

West, C., 1979: Against our will: male interruptions of females in cross-sex conversation. Pp. 81-97 in J. Orasanu, M. K. Slater and L. L. Adler (eds.), Language, Sex and Gender. (Annals of the New York Academy of Sciences, Volume 327). 1983; 'Ask me no questions. . $\therefore$ An analysis of queries and replies in physician-patient dialogues. Pp. 75-106 in S. Fisher and A. Todd (eds.), The Social Organization of Doctor-Patient Communication. Washington: Center for Applied Linguistics. 1984a: When the doctor is a 'lady': power, status and gender in physican-patient encounters. Symbolic Interaction 7: 87-106. 1984b: Medical misfires: mishearings, misgivings and misunderstandings in physician-patient dialogues. Discourse Processes 7: 107-134.

West, C. and D. H. Zimmerman, 1983: Small insults: a study of interruptions in cross-sex conversations between unacquainted persons. Pp. 102-117 in B. Thorne, C. Kramarae and N. Henley (eds.), Language, Gender and Society. Rowley: Newbury House.

Wideman, D., 1978: An initial examination into the structure of citizen-initiated police calls. Unpublished ms.: University of British Columbia.

Wilkinson, P. and C. Grace, 1975: Reforms as revolutions. Sociology 9: 397-418.

Wilson, T. P., 1985: Social structure and social interaction. University of California, Santa Barbara. Dept. of Sociology: unpublished ms.

Wootton, A.. 1975: Dilemmas of Discourse: Controversies About the Sociological Interpretation of Language. London: George Allen and Unwin.

Zimmerman, D. H., n. d.: Talk and its occasion: the case of calling the police. Mimeo: University of California, Santa Barbara.

Zimmerman, D. H. and C. West, 1975: Sex roles, interruptions and silences in conversation. Pp. 105-129 in B. Thorne and N. Henley (eds.), Language and Sex: Difference and Dominance. Rowley: Newbury House. 


\section{Appendix}

Transcribing Conventions (See Sacks, Schegloff and Jefferson, 1974: 731-734).

\section{I}

/I

'Interruption'.

Point at which a current speaker's turn is overlapped by the talk of another.

Speakers talking simultaneously.

Single parentheses indicate the transcriber was not sure about the words contained therein. Empty parentheses indicate that no 'hearing' was achieved. ((trails off)) Words in double parentheses indicate features of the audio materials other than actual verbalization.

Question intonation.

Pause in seconds.

Explosive aspiration.

Prior syllable prolonged.

'Latching', that is, no interval between the end of a prior and start of a next piece of talk.

Stress.

Point at which two overlapping utterances end. 